\title{
TTR
}

Traduction, terminologie, re?daction

\section{Wang Ning and Xu Yanhong, ed. Perspectives: Studies in Translatology. University of Copenhagen, Museum \\ Tusculanum Press, 1996.}

\section{Elizabeth Pong}

Volume 9, numéro 2, 2e semestre 1996

Parcours de traduction

Pathways of Translation

URI : https://id.erudit.org/iderudit/037266ar

DOI : https://doi.org/10.7202/037266ar

Aller au sommaire du numéro

Éditeur(s)

Association canadienne de traductologie

ISSN

0835-8443 (imprimé)

1708-2188 (numérique)

Découvrir la revue

Citer ce compte rendu

Pong, E. (1996). Compte rendu de [Wang Ning and Xu Yanhong, ed.

Perspectives: Studies in Translatology. University of Copenhagen, Museum

Tusculanum Press, 1996.] TTR, 9(2), 214-217. https://doi.org/10.7202/037266ar

Tous droits réservés ( $\mathrm{TTR}$ : traduction, terminologie, rédaction — Les auteurs, Ce document est protégé par la loi sur le droit d’auteur. L’utilisation des d'utilisation que vous pouvez consulter en ligne.

https://apropos.erudit.org/fr/usagers/politique-dutilisation/ 


\section{COMPTES RENDUS}

\section{Wang Ning and Xu Yanhong, ed. Perspectives : Studies in Translatology. University of Copenhagen, Museum Tusculanum Press, 1996'.}

This special issue on Chinese translation studies, edited by Wang Ning and $\mathrm{Xu}$ Yanhong, is an excellent attempt at putting together ten articles on developments in Chinese translation theories and translated works from 1811 to the present. They are the combined effort of scholars from China, Hong Kong and the United States. There are a number of bibliographies and they are presented in a systematic and thorough manner.

In his essay "An overview of the dissemination of Westem leaming in late-qing China," Xiong Yuezhi details four phases: from 1811 when Western books and learning were first introduced into China, to their proliferation, and then to prevailing conditions. Factors affecting the dissemination of Western leaming in China (p. 23), as well as five major themes which impacted the introduction of Western leaming during the period under review, have been identified.

Eva Hung's article on "The introduction of Dickens into China" provides a detailed analysis of reasons behind the sustained popularity of Dicken's novels in China in general, and A Tale of Two Cities in particular. From the time when Dickens' novels were introduced into China around 1906, much attention was focused on novelist-as-social-critic (p. 31). Translations of his novels exerted a lot of influence on a generation of writers of the post-May Fourth Movement. With the rise of socialist ideas from the late 1930s Dickens was perceived to be inadequate as he was afraid to point a finger at the

1. Address: Center for Translation Studies \& Lexicography, Njalsgade 96, DK-2300 Copenhagen S. Denmark. 
cause of this evil (p. 37), and the author explains why his popularity sustained.

Wang Ning's Essay On "Translation study in a context of comparative culture studies" starts out by questioning Yan Fu's principles of translation - 'faithfulness, ' 'expressiveness 'and 'elegance' ("The most important reason is that in literary translation into Chinese or vice versa, it is almost impossible to realize Yan's ideal criteria" (p. 45).). Wang asserts that there cannot be absolute equivalence in EnglishChinese or Chinese-English translations, but one can seek equivalence at the verbal, sentence, passage and textual level. Criteria for literary translation are: thorough understanding and identification with author and text, perfect rendition in fluency and preservation of style, polish without changing the original style; and making the translation retain the original culture code (pp. 47-48). This essay offers current perspective on Yan's principles on translation, giving readers much fruit for thought.

Eugene Chen Eoyang's essay on "Translating as a model of thinking; translation as a model of thought" is along the same theme but translation is approached from a philosophical perspective. He discusses the basic issues and processes involved in translation and puts forward his view of three different kinds of translation: the 'surrogate,' 'contingent' and 'co-evil.' Above all, "our understanding of transhations and translation theory cannot make significant progress unless we understand how we understand" (p. 68).

On the same subject, Xie Ming's essay on "Intercultural traduction: distance and appropriation" is based on the view that fundamentally interlingual translation is intercultural translation (p. 73). Because of cultural differences and different assumptions, one will find it easier to aim at "analogical" translation. The author concludes by pointing to the importance of "recontextualization" as proposed by Derrida (p. 86).

In his article "A socioemiotic approach to Chinese-English translation," Ke Ping analyses meaning from a sociosemiotic perspective, namely referential pragmatic and interpersonal meaning. Acknowledging that there is rarely exact equivalents in two different 
languages, the author proposes the following as the prerequisite to a faithful translation: "while striving to communicate the maximum number of meanings [...], the translator should give priority to the most prominent or important one(s), ensuring its/their correct transference in whatsoever circumstances and, if no other alternative is available, at the expense of the other meanings of the sign" (p. 99).

Yu Lan's article is about "Chomskian deep structure and translation." The author asserts that as it is rare for two different languages to have the same deep structure, one cannot "translate" the deep structure (pp. 106-107). There has also been some confusion among Chinese scholars attempting to apply 'deep structure' translations. The author proposes that "translation is a process in which the structural and transformational information of the source language sentence is drawn from the 'surface structure,' or logical form, of the source language and put into the target language to generate corresponding structures with the same structure and transformational information" (p. 110).

Examples from David Hawkes' translation of the Chinese classic A Dream of Red Mansions are cited by Han Jiaming in his essay on "Translation and interpretation." The author asserts that parts of Hawkes' translations are redundant and explanations are added. While they help the reader to be better informed, they also rob the reader of literary interpretation and cultural exploration. Hence the scholar and translator's role should be not confused. Annotations can provide additional information without detracting from the translation.

Also quoting specific passages from translations of $A$ Dream of Red Mansions, Cheng Mei writes of the limitations of the 'equivalent effect' in "Aesthetic Law and 'equivalent effect.' "Following the aesthetic law presented by Lin Xingzhai (p. 128), the author bases artistic charm on form, historical content and symbolization as reflected by translations of passages from $A$ Dream of Red Mansions. While citing instances of loss of equivalent artistic effect or images due to translation, the author says that all parties in the communication process, i.e. the author, the translator and the reader, should be taken into consideration as a prerequisite to more comprehensive, objective and effective studies of translation (p. 134). 
He Weixing based "The style of literary works in translation" on Scott Fitzgerald's The Great Gatsby as translated by Wu Ningkun's translation, and on English translations of Chinese poetry. He discusses how one can use sentence pattern, thetoric forms, jdiomatic expressions and diction of the original work to achieve stylistic fidelity. In literary translation one can search for connotation, association and contextual meaning.

This book is a very useful source of reference on ChineseEnglish and English-Chinese translations, encompassing history, comparison and appreciation of translations of major English and Chinese classics; and studies of theories of translation. Above all, it offers an analysis of how translation and translation theories have evolved in recent years, as well as pointing towards future trends.

\section{Eltzabeth Pong Conference Interpreter}

